\title{
Travel Motivations as Criteria in the Wellness Tourism Market Segmentation Process
}

\author{
Ana Težak Damijanić \\ Institute of Agriculture and Tourism, Croatia \\ tezak@iptpo.hr
}

The purpose of this paper is to explore travel motivations as criteria in the segmentation process of wellness tourists. Data was collected through a self-complete questionnaire on a sample of tourists staying in one out of 15 wellness hotels situated in four wellness tourism regions of the Republic of Croatia. Research was conducted from May through June in 2013. The data were processed using univariate, bivariate and multivariate statistics. Univariate statistics was used for a general description of the sample; bivariate analysis was applied to examine the differences among the clusters, while multivariate statistics was employed in order to determine the factors underlying the travel motivation construct and to discover the clusters. A total of nine travel motivation factors were identified by applying the theory of the push and pull travel motivations (three push motivation factors, and six pull motivation factors). Push travel motivation factors were labelled as Health trend, Relaxation and reward, and Novelty; pull motivation factors related to a wellness tourist product were labelled as Basic wellness, Intangible wellness, and Extra wellness, while pull motivation factors related to tourist destination were labelled as Cultural and natural heritage, Entertainment and recreation, and Landscape. Three clusters emerged by using travel motivation factors as segmentation criteria (high wellness, immaterial wellness, and low wellness clusters). Relaxation, wellness infrastructure and natural resources are important factors in wellness tourism research. However, both push and pull motivation factors are important variables in distinguishing among the segments.

Keywords: travel motives, market segmentation, wellness tourists, segmentation criteria

(cc)BY-SA https://doi.org/10.26493/2335-4194.13.201-213

\section{Introduction}

Due to the competitive nature of tourism, tourist destinations and tourism providers must focus their efforts on developing an adequate strategic plan for the wellness tourism market (Sheldon \& Park, 2008). In order to achieve this, it is necessary to get deeper insights into this market. Market segmentation may aid in the process of developing an adequate strategic plan. In general, market segmentation is used in different fields, e.g. retailing (Segal \& Giacobbe, 1994), and the online game industry (Lee et al., 2004); and different segmentation methodologies are applied, like ratings of proposed product design (Sewall, 1978), cost benefit approach (Winter, 1979), purchased-based market segmentation methodology (Tsai \& Chiu, 2004), etc. It is also widely applied in tourism settings, mostly with the purpose of determining the profile of tourists (Tkaczynski, 2009) and often focusing on different 
tourists' special interests like food (Su et al., 2020), recreation experience (Lee et al., 2018), and wine (Gu et al., 2018). However, to achieve appropriate results adequate segmentation criteria need to be selected (Dolnicar, 2008; Tkaczynski, 2009).

Selection of the segmentation criteria or base is the first step in the market segmentation process (Dolnicar, 2008; Yankelovich, 1964). Different criteria are used for segmentation purposes (Tkaczynski, 2009) and this problem is evident even in wellness tourism (Dryglas \& Salamaga, 2018; Mueller \& Lanz Kaufmann, 2001; Voigt et al., 2011; Mak et al., 2009; Hallab et al., 2003; Konu, 2010; Kim \& Batra, 2009). Namely, criteria like travel motives (Dryglas \& Salamaga, 2018; Huh et al., 2019), emotions (Sharma \& Nayak, 2019), lifestyle (Konu, 2010; Kucukusta \& Denizci Guillet, 2016) and benefits (Koh et al., 2010; Pesonen et al., 2011) are often used for segmentation purposes.

Wellness tourism is a form of special interest tourism and is considered as a certain niche market. However, different wellness tourist segments are detected (Dimitrovski \& Todorović, 2015; Dryglas \& Salamaga, 2017; Koh et al., 2010; Mueller \& Lanz Kaufmann, 2001) due to the usage of different variables as segmentation criteria. Thus, the purpose of this paper is to explore travel motivations as criteria in the segmentation process of wellness tourists. With this in mind, the goals of this paper are mainly twofold: (1) to determine travel motives dimensions of wellness tourists; and (2) to classify wellness tourists based on their travel motives. Therefore, this research contributes to theory and practice by analysing travel motives as criteria in the segmentation process of one special interest tourist segment. Furthermore, it highlights the most commonly identified travel motivations related to wellness tourists.

\section{Theoretical Background}

Market segmentation was first introduced in literature in order to make a clear distinction between market segmentation and product differentiation (Smith, 1956). It includes selection of the segmentation criterion/base, grouping of respondents, and profiling and managerial assessment of the usefulness of the market segments (Dibb, 1998; Dolnicar, 2008). The aim of market segmentation is to achieve the segments where members of one segment are as similar as possible to each other and where members of different segments are as different as possible (Dolnicar, 2008), thus selection of the appropriate variables used as segmentation criteria is crucial.

The market segmentation procedure in tourism does not differ compared to other industries, however, due to certain peculiarities of the tourism market, the main difference is evident in the segmentation criteria variables. Variables used as segmentation criteria are often divided into different categories (Swarbrooke \& Horner, 2007) like geographical (e.g. region), socioeconomic (e.g. occupation, income), demographic (e.g. age, gender, nationality), psychographic (e.g. lifestyle, attitudes, opinions and personality) and behaviouristic (e.g. loyalty, purchase occasion, benefits, user status, attitude). Although these variables are used in tourism settings as well, an additional category emerged, i.e. tourism specific segmentation criteria (Swarbrooke \& Horner, 2007).

Tourism-specific segmentation criteria includes variables like purpose of travel, travel motivations, and benefits received from the travel (Dimitrovski \& Todorović, 2015; Koh et al., 2010). Although travel motivation is often used for segmentation purposes (Bieger \& Laesser, 2002; Boksberger \& Laesser, 2008; Heung et al., 2001; Jönsson \& Devonish, 2008; Kozak, 2002; Sangpikul, 2008), variables in 'classical' segmentation criteria categories, like age, gender, education level, and income, are very often used for segmenting the tourist market (Tkaczynski, 2009). Therefore, to gain better understanding of tourist market segments, more frequent usage of tourism-specific segmentation criteria is desired, like travel motivations.

Travel motivations are inner drives that cause people to take action to satisfy their needs (Hudson, 2008). In tourism settings they are either analysed by grouping them considering different types of travel that share some common characteristics or by using a behavioural marketing approach (Middleton \& Clarke, 2001). The former is a more simplistic approach to travel motivations because travel motivations are presented in a very straightforward way. In contrast, the latter approach is a more complex one and it encom- 
passes different theories like behavioural theory of travel motivation, theory of classified purpose, theory of personal and/or interpersonal experiences in destination settings, theory of personal and/or interpersonal experiences in destination settings, etc. (Awaritefe, 2004; Chang, 2007). However, the theory of push and pull motivations is the most widely applied motivation theory within the behavioural approach and it will be examined in this paper.

The theory of push and pull motivations distinguishes between two main groups of factors that motivate tourists to travel: push factors and pull factors. Push factors refer to internal forces that motivate or create a desire to satisfy a need to travel, while pull factors are recognised as destination attributes (Kozak, 2002; Lubbe, 2003). Both groups of motivation factors are delineated by various dimensions, e.g. escape (Crompton, 1979; McGehee et al., 1996; Uysal \& Jurowski, 1993; Yoon \& Uysal, 2005), relaxation (Crompton, 1979; Kozak, 2002; McGehee et al., 1996; Suni \& Pesonen, 2019), education (Crompton, 1979; Yoon \& Uysal, 2005), heritage and culture (Kozak, 2002; McGehee et al., 1996; Uysal \& Jurowski, 1993), and comfort (McGehee et al., 1996). Health preservation and promotion may also be a travel motivation dimension. Additionally, preservation and promotion of one's health is one of the oldest motivators in tourism (Swarbrooke \& Horner, 2007).

Health as a travel motivation resulted in the creation of health tourism. Wellness tourism is regarded as a subcategory of health tourism and tourists whose prime aim is preserving or promoting their health are labelled as wellness tourists (Kim \& Batra, 2009; Mueller \& Lanz Kaufmann, 2001). Wellness tourists are usually interested in various programmes and treatments centred on health preservation and promotion, e.g. natural agents, exercise, anti-stress programmes, therapy, and beauty programmes (Andrijašević \& Bartoluci, 2004), although they may also include aspects like spirituality, and social interaction (Smith \& Puczkó, 2009). Therefore, the wellness tourist segment can be very heterogeneous.

The two main reasons why the wellness tourist segment is so heterogeneous are the numerous elements that can constitute a wellness tourist product (Chi, Chi
\& Ouyang, 2020; Smith \& Puczkó, 2009) and different segmentations basis (Chen et al., 2013, Dimitrovski \& Todorović, 2015; Dryglas \& Salamaga, 2017; Hallab, 2006; Kucukusta \& Denizci-Guillet, 2016; Mueller \& Lanz Kaufmann, 2001). Different wellness tourist product elements like natural agents, exercise, antistress programmes, therapy, beauty programmes (Andrijašević \& Bartoluci, 2004) may result in different sub-segments, e.g. demanding health guests, and independent infrastructure users (Mueller \& Lanz Kaufmann, 2001). Chi et al. (2020) have proposed a conceptual framework for wellness hotels that focuses on three main domains: physical wellness (fitness facilities and workout opportunities), mind wellness (mind wellness activities and education programmes), and environmental wellness (clean environment and healthy environment). Additionally, usage of different variables, e.g. lifestyle, travel motivations, and benefits, also yields different sub-segments (Azman \& Chan, 2010; Hallab, 2006; Konu \& Laukkanen, 2009; Mak et al., 2009).

The push and pull motivation theory is also used for analysing the travel motivation of wellness tourists in general (Bennett et al., 2004; Hallab, 2006; Konu \& Laukkanen, 2009; Mak et al., 2009; Mueller \& Lanz Kaufmann, 2001), examining the link between travel motives, and satisfaction and behaviour intentions (Kim et al., 2017; Lim et al., 2016) and for determining different sub-segments (Dimitrovski \& Todorović, 2015; Dryglas \& Salamaga, 2017; 2018; Huh et al., 2019). In analysis of travel motivation in wellness tourism, certain scholars have examined both the push and the pull travel motivation factors (Azman \& Chan, 2010; Hallab, 2006), only push travel motivation factors (Dimitrovski \& Todorović, 2015; Dryglas \& Salamaga, 2018; Huh et al., 2019; Koh et al., 2010; Konu \& Laukkanen, 2009; Lim et al., 2016; Mak et al., 2009; Voigt et al., 2011) or only pull travel motivation factors (Chen et al., 2013; Dryglas \& Salamaga, 2017; Mueller \& Lanz Kaufmann, 2001).

By examining both push and pull travel motivations, Hallab (2006) found five push motivation factors (healthy living, excitement, education, indulgence and escape) and five pull motives (health and fitness, hygiene and the environment, history and nature, vig- 
ilance and health, and arts and urban luxury), while Azman and Chan (2010) identified three push motivation factors (escape - relay and pamper, destress/time out, and regeneration) and two pull motivation factors (tangible resources and marketing image). Focusing exclusively on pull travel motivation, Chen et al. (2013) identified eight pull motivation factors (Personnel services, Health promotion treatments, Environments, Healthy diet, Relaxation, Social activities, Experience of unique tourism resources, Mental learning), and Dryglas and Salamaga (2017) found four pull motivation factors: Natural resources, Cultural and natural environment, Spa/Wellness infrastructure and Social and political environment.

However, most of the research regarding travel motivation of wellness tourists focused on push motivation. With push motivation in mind, Mak et al. (2009) discovered five push motivation factors (friendship and kinship, health and beauty, self-reward and indulgence, relaxation and relief, and escape); Konu and Laukkanen (2009) determined seven push motivation factors (self-development, healthy and physical activity, relaxation and escape, isolation and nostalgia, nature, autonomy and stimulation, and social status); Koh et al. (2010) found four push motivation factors (Social, Relaxing, Healthy, and Rejuvenating); Voigt et al. (2011) uncovered six push travel motivations (Transcendence, Physical health and appearance, Escape and relaxation, Important others and novelty, Reestablish self-esteem, Indulgence); Dimitrovski and Todorović (2015) detected six push motivation factors (Rejuvenating, Socialization and excitement, Hedonism, Obsession with health and beauty, Relaxation, Escape); and Lim et al. (2016) determined four push motivation factors (Relaxation and rest, Selfexploration, Accessibility, and Novelty). In their further work regarding wellness travel motivation, Dryglas and Salamaga (2018) focused on push travel motives and have determined four factors (spiritual and medical care, entertainment and networking, relaxation, and aesthetics). Huh et al. (2019) suggest three new wellness push motivations, namely tourism factor, prevention factor and treatment factor.

In summary, there is no consensus related to the travel motivation dimensions, and the main result is evident in the detection of different wellness tourists segments, e.g. demanding health guests, independent infrastructure users, care-intensive cure guests and undemanding recreation guests (Mueller \& Lanz Kaufmann, 2001); escapists, neutralists and hedonists (Koh et al., 2010); socially active tourists, and self-focused tourists (Dimitrovski \& Todorović, 2015); nature and culture seekers, spa/wellness seekers, and social contact seekers (Dryglas \& Salamaga, 2017): pleasure pursuers, healing pursuers and relaxation pursuers (Dryglas and Salamaga, 2018); and wellness and treatment seekers, treatment seekers, and tourism, treatment and wellness seekers (Huh et al., 2019).

\section{Methodology}

The target population included those tourists who visited hotels offering wellness as an additional tourist product. This study focused on guests staying in wellness hotels because it was a part of a larger research linking health, travel motives and customer value. The survey was conducted from May to June in 2013 in 15 hotels situated in a coastal part of Croatia. For the purpose of sampling, a list of hotels that were members of the Croatian Wellness Tourism Association was obtained. In 2012, a total of 65 hotels in Croatia were members of this Association, and Croatia was divided into 10 regions (Table 1). Most of the hotels were situated in the Istria and Kvarner regions ( 16 hotels in each region), while the Dubrovnik and Split regions were second (9 hotels in each region). Hotels were mostly categorised as four-star hotels (40 hotels), while only 17 hotels had five stars. Therefore, regional dispersion and hotel category were used in designing the sample. Hotels situated in four wellness regions, namely the Istria, Kvarner, Split, and Dubrovnik regions were taken into account because they had hotels with wellness centres categorised as three-star, four-star and five-star hotels.

In the process of onsite data collection, the researcher was stationary while the responders were mobile (Veal, 2006). Hotel guests were approached by the researcher and asked to participate in the survey. The researcher explained the purpose of the survey, stated that the survey was anonymous, and handed out a questionnaire in the appropriate language. Data was 
Table 1 Accommodation Facilities with Wellness Centres in Croatia in 2012

\begin{tabular}{lrrrrr}
\hline Region & $(1)$ & $(2)$ & $(3)$ & $(4)$ & $(5)$ \\
\hline Istria & 17 & 16 & 1 & 11 & 4 \\
Kvarner & 19 & 16 & 4 & 8 & 4 \\
Dalmatia - Zadar & 7 & 5 & 1 & 3 & 1 \\
Dalmatia - Šibenik & 2 & 1 & 0 & 1 & 0 \\
Dalmatia - Split & 9 & 9 & 0 & 7 & 2 \\
Dalmatia - Dubrovnik & 10 & 9 & 1 & 3 & 5 \\
Lika (Karlovac) & 1 & 1 & 0 & 1 & 0 \\
Central Croatia & 7 & 4 & 1 & 3 & 0 \\
Zagreb & 4 & 2 & 0 & 1 & 1 \\
Slavonia & 2 & 2 & 0 & 2 & 0 \\
\hline Total & 78 & 65 & 8 & 40 & 17 \\
\hline Notes Column & &
\end{tabular}

Notes Column headings are as follows: (1) number of wellness community members, (2) total number of hotels with wellness centres, (3) three-star hotels, (4) four-star hotels, (5) five-star hotels.

collected through a self-complete questionnaire. The questionnaire consisted of 15 questions that were divided into four sections: (1) wellness-related lifestyle, (2) perceived value, (3) motivational factors and (4) respondents' characteristics. It was originally designed in Croatian and then back-translated into English, German, Italian, Russian, French, Spanish, and Slovenian. No changes were made to the original translations because the only detected differences were in the usage of different synonyms. As a self-complete questionnaire was administered, the minimal number of 300 responders was set to satisfy the requirement for performing a data analysis (Hair et al., 2010).

The data were processed using statistical methods consisting of descriptive statistics, bivariate and multivariate. Descriptive statistics was used to provide a general description of the sample; bivariate statistics was applied to examine the differences among the clusters, while multivariate statistics was employed in order to determine the factors underlying the travel motivation construct and to discover the clusters. The individual items were examined through checks for accuracy of data entry, missing data and distribution. The cases with the missing values were replaced using an мсмC method for item imputation. Exploratory factor analysis was done using maximum likelihood factor analysis and promax rotation with an eigenvalue of 1.00 or more being used to identify potential factors. Internal reliability was determined by computing Cronbach's alpha. Travel motivation factors were calculated as a mean value for each respondent (DiStefano et al., 2009).

The responders were a posteriori grouped based on the importance they placed on various travel motivations factors. The number of clusters was determined by splitting the sample and using the hierarchical clustering technique. A hundred observations were randomly selected. The Ward method, with squared Euclidean distance, was used to establish the preliminary number of clusters. A three-cluster solution was selected on the basis of the largest and most plausible proportionate change. A non-hierarchical cluster analysis procedure ( $k$-means) was utilised to finalise the cluster solutions using the a priori determined number of clusters. Cluster validation was done using a one-way ANOVA analysis and five measures that were not included as travel motivation items (Hair et al., 2010).

A five-point Likert scale (ranging from 1 - totally not important to 5 - totally important) was used to measure the travel motivation factors' perceived importance. Items measuring travel motivation factors were divided into two main groups based on the theory of push and pull motivation factors and were adopted from general travel motivation literature (tourist destination pull factors) and wellness tourism motivation literature (push factors and wellness tourist product pull factors). A total of 18 items were used for measuring push factors (Bennett et al., 2004; Kim \& Batra, 2009; Koh et al., 2010; Konu \& Laukkanen, 2009; Mak et al., 2009; Monteson \& Singer, 2004; Pesonen et al., 2011; Voigt et al., 2011). Pull factors were divided into two sub-groups: wellness tourist product and tourist destination. A total of 24 items were used for measuring the first group of pull factors (Andrijašević \& Bartoluci, 2004; Bennett et al., 2004; Mak et al., 2009; Mueller \& Lanz Kaufmann, 2001; Pesonen et al., 2011), while 20 items were used for measuring the second group (Awaritefe, 2004; 
Table 2 Descriptive Statistics and Results of Explanatory Factor Analysis of Push Travel Motivations

\begin{tabular}{|c|c|c|c|c|c|}
\hline Variables & Mean & SD & Factor 1 & Factor 2 & Factor 3 \\
\hline Get in better shape & 2.78 & 1.379 & 0.838 & & \\
\hline Health improvement & 3.01 & 1.331 & 0.754 & & \\
\hline Feel younger & 2.55 & 1.361 & 0.733 & & \\
\hline Weight control interest & 2.26 & 1.311 & 0.713 & & \\
\hline Practice healthy lifestyle & 2.94 & 1.322 & 0.699 & & \\
\hline Feel healthier & 3.11 & 1.373 & 0.670 & & \\
\hline Visit trendy place & 2.43 & 1.338 & 0.619 & & \\
\hline Stress release & 4.26 & 1.050 & & 0.808 & \\
\hline Escape from everyday life & 3.99 & 1.213 & & 0.612 & \\
\hline Reward for hard work & $3 \cdot 72$ & 1.286 & & 0.607 & \\
\hline Stay in quiet and peaceful place & $3 \cdot 99$ & 1.138 & & 0.520 & \\
\hline Interest in landscape & 3.73 & 1.291 & & & -0.828 \\
\hline Get to know other cultures & $3 \cdot 46$ & 1.318 & & & -0.800 \\
\hline Try new things & 3.58 & 1.203 & & & -0.455 \\
\hline Eigenvalues & & & 5.242 & 1.949 & 1.367 \\
\hline Percentage of variance & & & 34.162 & 10.215 & 6.736 \\
\hline Percentage of cumulative variance & & & 34.162 & 44.377 & 51.113 \\
\hline Cronbach's $\alpha$ & & & 0.888 & 0.733 & 0.759 \\
\hline
\end{tabular}

Crompton, 1979; Heung et al., 2001; Jönsson \& Devonish, 2008; Kozak, 2002; McGehee et al., 1996; Yoon \& Uysal, 2005). This list was examined by four tourism experts to achieve content adequacy (Hinkin et al., 1997).

\section{Results and Discussion}

In all, 548 responders were used in the analysis. Most of the responders stayed in four-star hotels in the Istria or Kvarner region. The proportion of female responders (56\%) was slightly higher than that of males (44\%). A majority of the responders were between 35 and 54 years of age (48\%). Most of them had obtained higher education (68\%). In general, the responders were employees (45\%), 16\% were self-employed and approximately $14 \%$ were managers. Most of them were from Austria (23\%) and Germany (23\%), almost $11 \%$ were from the $\mathrm{UK}$, and about $10 \%$ originated from Italy. The most frequent monthly net income was between $€ 1,000$ and $€ 2,000$ (38\%). Almost $65 \%$ of the respon- ders came to the hotel with their partner. About $2 / 3$ of the responders visited the hotel for the first time, but most of them (57\%) had already visited the region. Half of the responders obtained information about the hotel using the Internet, travel agencies were the second source of information $(35 \%)$, while recommendation from friends and relatives was the third information source (20\%).

To identify dimensions of push and pull travel motivation, three exploratory factor analyses were done. Items with loading below 0.04 and cross-loadings were deleted, resulting in retention of 14 push travel motivations items (Table 2), 17 pull travel motivations for wellness tourist product items (Table 3), and 15 pull travel motivations for tourist destination items (Table 4).

The push travel motivations means (Table 2) varied from 2.26 ('Weight control interest') to 4.26 ('Stress release'). Initially five factors were detected, however, after purifying the scale, three factors representing 
Table 3 Descriptive Statistics and Results of Explanatory Factor Analysis of Pull Travel Motivations: Wellness Tourist Product

\begin{tabular}{|c|c|c|c|c|c|}
\hline Variables & Mean & SD & Factor 1 & Factor 2 & Factor 3 \\
\hline Sauna & 2.52 & 1.482 & 0.862 & & \\
\hline Steam bath & 2.47 & 1.450 & 0.857 & & \\
\hline Solarium & 2.02 & 1.282 & 0.651 & & \\
\hline Massage (traditional) & 2.86 & 1.433 & 0.619 & & \\
\hline Range of health amenities & 3.00 & 1.403 & 0.568 & & \\
\hline Massage (alternative) & 2.97 & 1.427 & 0.485 & & \\
\hline Beauty treatments & 2.61 & 1.398 & 0.431 & & \\
\hline Atmosphere & 4.44 & 0.878 & & 0.887 & \\
\hline Relaxation & $4 \cdot 36$ & 1.021 & & 0.732 & \\
\hline Surroundings & 4.33 & 0.910 & & 0.663 & \\
\hline Competence & 4.11 & 1.060 & & 0.531 & \\
\hline Tips for back home & 2.65 & 1.356 & & & -0.804 \\
\hline Understanding special needs & 3.05 & 1.406 & & & -0.714 \\
\hline Supervised Sport & 2.52 & 1.363 & & & -0.697 \\
\hline Detoxification & 2.85 & 1.427 & & & -0.663 \\
\hline Tai Chi, Yoga and similar activities & 2.39 & 1.369 & & & -0.590 \\
\hline Mud baths/wraps & 2.26 & 1.330 & & & -0.575 \\
\hline Eigenvalues & & & 7.654 & 2.379 & 1.186 \\
\hline Percentage of variance & & & 42.718 & 11.499 & 4.635 \\
\hline Percentage of cumulative variance & & & 42.718 & 54.217 & 58.852 \\
\hline Cronbach's $\alpha$ & & & 0.912 & 0.800 & 0.881 \\
\hline
\end{tabular}

push travel motivations formed clear factor structures. Jointly, they accounted for $51.11 \%$ of accumulated variance, and most of the factor loadings were greater than o.6o. They were labelled as Health trend, Relaxation and reward, and Novelty. Cronbach's alpha coefficients were between 0.733 and 0.888 . Health trend was comprised of different items related to getting healthier and in better shape. Relaxation and reward included items like stress release, escape from everyday problems, and the feeling of being rewarded. Novelty encompassed various items regarding learning about new things. In general, push travel motivations related to health aspects and luxury were mostly unimportant, while those push travel motivations that emphasise interest in learning new things, and relaxation and reward were mostly important to the responders.
The detection of these three push travel motivation factors are partially supported by the findings of Hallab (2006), Mak et al. (2009), Konu and Laukkanen (2009), Koh et al. (2010), Voigt et al. (2011), Dimitrovski and Todorović (2015), Lim et al. (2016), Dryglas and Salamaga (2018), and Huh et al. (2019). Relaxation as a push motivation factor was the factor most commonly identified in research regarding wellness tourists (Dimitrovski \& Todorović, 2015; Koh et al., 2010; Konu \& Laukkanen, 2009; Lim et al., 2016; Mak et al., 2009; Voigt et al., 2011).

The pull travel motivations means related to a wellness tourist product (Table 3) varied from 2.02 ('Solarium') to 4.44 ('Atmosphere'). Originally four factors were detected, however, after purifying the scale, three factors representing pull travel motivations for a well- 
Table 4 Descriptive Statistics and Results of Explanatory Factor Analysis of Pull Travel Motivations: Tourist Destination

\begin{tabular}{|c|c|c|c|c|c|}
\hline Variables & Mean & SD & Factor 1 & Factor 2 & Factor 3 \\
\hline Variety of architectural styles & 3.14 & 1.309 & 0.769 & & \\
\hline Theatre and performances & 2.49 & 1.263 & 0.693 & & \\
\hline Cultural heritage & 3.44 & 1.257 & 0.690 & & \\
\hline Diversity of attractions & $3 \cdot 34$ & 1.295 & 0.613 & & \\
\hline Natural protected areas & 3.32 & 1.276 & 0.525 & & \\
\hline Variety of entertainment activities & 3.13 & 1.175 & & 0.835 & \\
\hline Entertainment possibilities & 3.43 & 1.112 & & 0.734 & \\
\hline Shopping possibilities & 2.90 & 1.225 & & 0.655 & \\
\hline Local events & 2.91 & 1.254 & & 0.639 & \\
\hline Sports and recreation & 3.29 & 1.176 & & 0.580 & \\
\hline Variety of cultural events & 3.17 & 1.164 & & 0.535 & \\
\hline Beautiful nature & 4.24 & 0.949 & & & 0.781 \\
\hline Ecological preservation of the destination & 3.83 & 1.148 & & & 0.694 \\
\hline Climate & 4.12 & 0.949 & & & 0.540 \\
\hline Picturesqueness and tidiness of the place & 3.86 & 1.131 & & & 0.498 \\
\hline Eigenvalues & & & 5.687 & 1.758 & 1.187 \\
\hline Percentage of variance & & & 35.542 & 10.988 & 7.418 \\
\hline Percentage of cumulative variance & & & 35.542 & 46.530 & 53.948 \\
\hline Cronbach's $\alpha$ & & & 0.877 & 0.850 & 0.767 \\
\hline
\end{tabular}

Table 5 Results of Cluster Analysis

\begin{tabular}{lrrrr}
\hline Measures & $(1)$ & $(2)$ & $(3)$ & $(4)$ \\
\hline Health trend & 2.37 & 3.55 & 1.99 & $185.886^{* * *}$ \\
Relaxation and reward & 3.96 & 4.28 & 3.56 & $30.642^{\star * *}$ \\
Novelty & 3.95 & 4.09 & 2.24 & $319.312^{* * *}$ \\
Basic wellness & 1.81 & 3.58 & 2.41 & $238.519^{* * *}$ \\
Extra wellness & 1.82 & 3.59 & 2.32 & $299.989^{* * *}$ \\
Intangible wellness & 4.22 & 4.60 & 3.98 & $31.867^{* * *}$ \\
Cult. and nat. heritage & 3.22 & 3.57 & 1.96 & $178.557^{\star * *}$ \\
Enter. and recreat. & 3.09 & 3.65 & 2.41 & $110.843^{* * *}$ \\
Landscape & 4.18 & 4.30 & 3.30 & $92.655^{* * *}$ \\
\hline Notes Column headings are as follows: (1) cluster 1- im- \\
material wellness, (2) cluster $2-$ high wellness, (3) cluster 3 \\
- low wellness, (4) F-value. ${ }^{* * *}$ Significant at o.oo1.
\end{tabular}

ness tourist product formed clear factor structures. Jointly, they accounted for $58.85 \%$ of accumulated vari- ance, and most of the factor loadings were greater than o.6o. They were labelled as Basic wellness, Intangible wellness, and Extra wellness. Cronbach's alpha coefficients were between 0.800 and 0.912 . Basic wellness included aspects like massage and sauna; intangible wellness encompassed various items that correspond to intangible aspects of a tourist product e.g. atmosphere and interactions, while extra wellness included attributes like detoxification, Tai Chi, etc. In general, pull travel motivations related to tangible aspects of a wellness tourist product, like Sauna, Solarium, Massages and Steam bath, were mostly unimportant, while the intangible aspects of a wellness tourist product (competence, relaxation and atmosphere) were mostly important to the responders. The detection of these three pull travel motivation factors are partially supported by the findings of Azman and Chan (2010), and Chen et al. (2013).

The pull travel motivations means related to tourist 
destination (Table 4) varied from 2.49 ('Theatre and performances') to 4.24 ('Beautiful nature'). At first, four factors were detected, however, after purifying the scale, three factors representing pull travel motivations for tourist destination formed clear factor structures. Jointly, they accounted for $53.95 \%$ of accumulated variance, and most of the factor loadings were greater than o.6o. They were labelled as Cultural and natural heritage, Entertainment and recreation, and Landscape. Cronbach's alpha coefficients were between 0.767 and 0.877. Cultural and natural heritage was comprised of different items like theatre, architectural styles, and natural protected area. Entertainment and recreation encompassed various activities and objects regarding entertainment, shopping, and sports. Landscape was composed of items referring to geographical features of the tourist destination. The pull travel motivations were mainly important to responders. However, certain cultural activities (e.g. museums and exhibitions, and theatre and performances) and activities related to tourists' special interests (like shopping and events) were marked as rather unimportant. The detection of these three pull travel motivation factors is partially supported by the findings of Hallab (2006), Chen et al. (2013), and Dryglas and Salamaga (2017). Natural resources were identified as a pull travel motivation in all three cases.

The travel motivations dimensions were cluster analysed. The number of clusters was determined by splitting the sample and using the hierarchical clustering technique. A hundred observations were randomly selected. The Ward method, with squared Euclidean distance, was used to establish the preliminary number of clusters. A three-cluster solution was selected on the basis of the largest and most plausible proportionate change. A non-hierarchical cluster analysis procedure ( $k$-means) was utilised to finalise the cluster solutions using the a priori determined number of clusters. The latter procedure confirmed the three-cluster solution (Table 5 and Table 6). The identified clusters were named according to the cluster centroids. Cluster 2 $(N=210)$, being the largest, represented $38.3 \%$ of the guests staying in wellness hotels, while Cluster $3(\mathrm{~N}$ $=133$ ) was the smallest and represented $24.3 \%$ of the guests staying in wellness hotels. Cluster $1(N=205)$ represented $37.4 \%$ of the guests staying in wellness hotels. Although the clusters differed statistically in all nine measures, dimensions that may be considered as more of an intangible kind stood out, i.e. push motivation factors (Relaxation and reward, and Novelty), pull motivation factors (Intangible wellness, as well as Cultural and natural heritage, Entertainment and recreation, and Landscape). Thus, the clusters were subsequently named taking into account these variables.

The guests staying in wellness hotels in Cluster 3 expressed a very low level of importance, or rather unimportance, related to travel motives in general, therefore this cluster was labelled as 'Low wellness.' In contrast, the guests staying in wellness hotels in Cluster 2 expressed the highest importance on all travel motivation dimensions; hence, this cluster was labelled 'High wellness.' Intangible travel motivation dimensions were the variables that differentiated Cluster 1 from the other two clusters, consequently labelling this cluster as 'Immaterial wellness.' The application of travel motivations in wellness tourism settings resulted in three clusters (high wellness, immaterial wellness, and low wellness clusters). The number of identified clusters is in accordance with the findings of Koh et al. (2010), Dryglas and Salamaga (2017), Dryglas and Salamaga (2018) and Huh et al. (2019), who also uncovered three clusters. However, the characteristics of clusters is only partially supported by the findings of Mueller and Lanz Kaufmann (2001), Koh et al. (2010), Dimitrovski and Todorović (2015), Dryglas and Salamaga (2017), Dryglas and Salamaga (2018) and Huh et al. (2019).

In all, 5 measures related to travel motivations that were not included in previous analyses were used to validate the clusters. All of them were significant, verifying the statistical differences among the clusters and providing support for the criterion validity of the items (Table 6).

\section{Conclusion}

This paper explores travel motivations as criteria in the segmentation process of one market niche, more precisely wellness tourism. A total of nine travel motivation factors were identified by applying the theory 
Table 6 ANovA Results for Cluster Validation

\begin{tabular}{|c|c|c|c|c|c|c|c|}
\hline \multirow[t]{2}{*}{ Measures } & \multicolumn{2}{|c|}{ Cluster 1} & \multicolumn{2}{|c|}{ Cluster 2} & \multicolumn{2}{|c|}{ Cluster 3} & \multirow[t]{2}{*}{$F$-value } \\
\hline & Mean & SD & Mean & SD & Mean & SD & \\
\hline Enjoy being pampered & 2.8 & 1.28 & 3.6 & 1.18 & 2.2 & 1.16 & $55.975^{* * *}$ \\
\hline Want to have fun & 3.6 & 1.18 & 4.1 & 0.99 & 3.2 & 1.32 & $27.042^{\star * *}$ \\
\hline Organised short time trips & 2.9 & 1.37 & 3.5 & 1.14 & 2.1 & 1.20 & $55.164^{\star * *}$ \\
\hline Personalised service & 2.6 & 1.35 & $3 \cdot 9$ & 0.97 & 2.7 & 1.40 & $65.001^{* * *}$ \\
\hline Healthy diet & 4.0 & 1.08 & 4.4 & 0.71 & 3.8 & 1.19 & $22.638^{\star * *}$ \\
\hline
\end{tabular}

Notes $\quad * * *$ Significant at 0.001 .

of the push and pull travel motivations. Three push motivation factors of wellness tourists emerged. They were labelled as Health trend, Relaxation and reward, and Novelty. A group of motivations related to interest in learning new things, and relaxation and reward stood out as important motives to wellness tourists in general, while items related to health aspects and luxury were mostly unimportant. A total of six pull travel motivation factors were established; three motivation factors related to a wellness tourist product and three motivation factors related to tourist destination. Motivation factors related to a wellness tourist product were labelled as Basic wellness, Intangible wellness, and Extra wellness, while those motivation factors related to tourist destination were labelled as Cultural and natural heritage, Entertainment and recreation, and Landscape. Pull travel motivations related to tangible aspects of a wellness tourist product, presented through basic and extra wellness factors, were mostly unimportant, while items measuring the intangible wellness factor were mostly important to the responders. The pull travel motivation factors related to tourist destination were mainly important to responders. However, certain cultural activities (e.g. museums and exhibitions, and theatre and performances) and activities related to tourists' special interest (like shopping and events) were marked as rather unimportant. By using travel motivation as segmentation criteria in wellness tourism settings three clusters were detected. They were labelled as high wellness, immaterial wellness, and low wellness clusters. The high wellness cluster placed high importance on all nine travel motivation factors. Pull motivation factors related to a well- ness tourist product were important in distinguishing between the high wellness segment, and immaterial and low wellness segments, while pull factors related to the destination provided differences between immaterial and high wellness segments, and the low wellness segment. In contrast, push travel motivations were mostly important to all three segments, with only health trend being the motivation factor that stood out in differentiating between the high wellness segment, and the other two.

This paper suggests that both push and pull motivation factors are crucial in the market segmentation process of wellness tourism as a form of niche market. Relaxation as push motivation, wellness infrastructure and natural resources as pull motivation factors are important factors in wellness tourism research. However, push travel motivations related to health issues are vital in differentiation between segments that are highly wellness-oriented and those who are less wellness oriented, i.e. who are more oriented on achieving well-being. The findings have certain implications for tourism managers. This research provides deeper insights into sub-segments of wellness tourists. Thus, in hotels where a wellness tourist product is an additional tourist product, and not the main focus, there may be a certain number of guests who are more interested in intangible wellness aspects like atmosphere, relaxation, and surroundings, compared to tangible wellness aspects. Thus, they do not place importance on tangible wellness aspects and are not likely to use services like massage, sauna, mud baths/wraps, etc. The findings also suggest that tourist destination attributes play an important role for hotel guests who are inter- 
ested in a wellness tourist product as well as for those guests who are more interested in immaterial aspects provided by the wellness concept.

There are certain limitations of this study. This study included guests staying in wellness hotels that offer wellness as an additional tourist product. Therefore, future research could include hotels and resorts that are exclusively focused on wellness. This study was focused on wellness travel motivation and its suitability as segmentation criteria. Therefore, future research may focus on other variables used for segmentation purposes like lifestyle. This research did not include tourists with disabilities or other medical conditions; therefore, future research might focus on these segments as well. The research was conducted in 2013 and since then certain strategic changes may have influenced wellness tourism. Therefore, a similar type of research would be useful to investigate the national tourism strategies' impact on wellness tourism, i.e. wellness hotels.

\section{References}

Andrijašević, M., \& Bartoluci, M. (2004) The role of wellness in contemporary tourism. Acta Turistica, 16(2), 125-142.

Awaritefe, O. D. (2004). Motivations and other considerations in tourism destination choice: A case study of Nigeria. Tourism Geographies, 6(3), 303-330.

Azman, I., \& Chan, K. L. J. (2010). Health and spa tourism business: Tourists' profiles and motivational factors, health, wellness and tourism: Healthy tourists, healthy business? In Proceedings of the Travel and Tourism Research Association Europe 2010 Annual Conference, (pp. 9-24). http://pc.parnu.ee/ htooman/

Proceedingnyomdanak.pdf

Bennett, M., King, B., \& Milner, L. M. (2004). The health resort sector in Australia: A positioning study. Journal of Vacation Marketing, 10(2), 122-137.

Bieger, T., \& Laesser, C. (2002). Market segmentation by motivation: The case of Switzerland. Journal of Travel Research, 41(1), 68-76.

Boksberger, P., \& Laesser, C. (2008). Segmenting the senior travel market by means of travel motivation - Insights from a mature market (Switzerland). http://ro.uow.edu .au/cgi/viewcontent.cgi? article $=3489 \&$ context =commpapers

Chang, J. C. (2007). Travel motivation of package tour travellers. Tourism, 55(2), 157-176.
Chen, K. H., Liu, H. H., \& Chang, F. H. (2013). Essential customer service factors and the segmentation of older visitors within wellness tourism based on hot springs hotels. International Journal of Hospitality Management, 35, 122132.

Crompton, J. L. (1979). Motivations for pleasure vacations. Annals of Tourism Research, 6(4), 408-424.

Dimitrovski, D., \& Todorović, A. (2015). Clustering wellness tourists in spa environment. Tourism Management Perspectives, 16, 259-265.

DiStefano, C., Zhu, M., \& Mîndrilă, D. (2009). Understanding and using factor scores: Considerations for the applied research. Practical Assessment Research \& Evaluation, 14(20), 1-11.

Dolnicar, S. (2008). Market segmentation in tourism. In A. G. Woodside \& D. Martin (Eds.), Tourism management: Analysis, behaviour and strategy (pp. 129-150). С A B I.

Dryglas, D., \& Salamaga, M. (2017). Applying destination attribute segmentation to health tourists: A case study of Polish spa resorts. Journal of Travel and Tourism Marketing, 34(4), 503-514.

Dryglas, D., \& Salamaga, M. (2018). Segmentation by push motives in health tourism destinations: A case study of Polish spa resorts. Journal of Destination Marketing \& Management, 9, 234-246.

Gu, Q., Zhang, H. Q., King, B., \& Huang, S. (2018). Wine tourism involvement: A segmentation of Chinese tourists. Journal of Travel \& Tourism Marketing, 35(5), 633648.

Hair, J. F., Black, W. C., Babin, B. J., \& Anderson, A. E. (2010). Multivariate data analysis. Pearson Prentice Hall.

Hallab, Z. (2006). Catering to the healthy-living vacationer. Journal of Vacation Marketing, 12(1), 71-91.

Hallab, Z. A. A., Yoon Y., \& Uysal, M. (2003). An identification of market segments based on healthy-living attitude. Journal of Hospitality and Leisure Marketing, $10(3 / 4), 185-198$.

Heung, V. C. S., Qu, H., \& Chu, R. (2001). The relationship between vacation factors and socio-demographic and travelling characteristics: The case of Japanese leisure travellers. Tourism Management, 22(3), 259-269.

Hinkin, T. R., Tracey, J. B., \& Enz, C. A., (1997). Scale construction: Developing reliable and valid measurement instruments. Journal of Hospitality and Tourism Research, 21(1), 100-120.

Hudson, S. (2008). Tourism and hospitality marketing: A global perspective. Sage.

Huh, C., Lee, M. J., \& Lee, S. (2019). A profile of spa-goers in the U.S. luxury hotels and resorts: A posteriori market 
segmentation approach. Journal of Hospitality Marketing \& Management, 28(8), 1032-1052.

Jönsson, C., \& Devonish, D. (2008). Does nationality, gender, and age affect travel motivations? A Case of Visitors to the Caribbean Island of Barbados. Journal of Travel and Tourism Marketing, 25(3/4), 398-408.

Kim, B. H., \& Batra, A. (2009). Healthy-living behavior status and motivational characteristics of foreign tourists to visit wellness facilities in Bangkok. In The 2nd Annual PSU Phuket Research Conference proceedings (pp. 1-8). http://www.conference.phuket.psu.ac.th/PSU_OPEN _WEEK_2009/data/Hospitality/Paper6.pdf

Kim, E., Chiang, L., \& Tang, L. (2017). Investigating wellness tourists' motivation, engagement, and loyalty: In search of the missing link. Journal of Travel \& Tourism Marketing, 34(7), 867-879.

Koh, S., Yoo, J. J. E., \& Boger, C. A. Jr. (2010). Importanceperformance analysis with benefit segmentation of spa goers. International Journal of Contemporary Hospitality Management, 22(5), 718-735.

Konu, H. (2010). Identifying potential wellbeing tourism segments in Finland. Tourism Review, 65(2), 41-51.

Konu, H., \& Laukkanen, T. (2009). Roles of motivation factors in predicting tourists' intentions to make wellbeing holidays - A Finnish case. In ANZMAC 2009 conference proceedings (pp. 1-9). http://www.duplication.net.au/ ANZMACo9/papers/ANZMAC2009-376.pdf

Kozak, M. (2002). Comparative analysis of tourist motivations by nationality and destination. Tourism Management, 23(3), 221-232.

Kucukusta, D., \& Denizci Guillet, B. (2016). Lifestyle segmentation of spa users: A study of inbound travelers to Hong Kong. Asia Pacific Journal of Tourism Research, 21(3), 239-258.

Lee, S. C., Suh, Y. H., Kim, J. K., \& Lee, K. J. (2004). A crossnational market segmentation of online game industry using som. Expert Systems with Applications, 27(4), 559570 .

Lee, T. H., Jan, F.-H., Tseng, C. H., \& Lin, Y. F. (2018). Segmentation by recreation experience in island-based tourism: A case study of Taiwan's Liuqiu Island. Journal of Sustainable Tourism, 26(3), 362-378.

Lim, Y.-J., Kim, H.-K., \& Lee, T. J. (2016). Visitor motivational factors and level of satisfaction in wellness tourism: Comparison between first-time visitors and repeat visitors. Asia Pacific Journal of Tourism Research, 21(2), 137-156.

Lubbe, B. A. (2003). Tourism management in Southern Africa. Pearson Education.
Mak A. H. N., Wong, K. K. F., \& Chang R. C. Y. (2009). Health or self-indulgence? The motivations and characteristics of spa-goers. International Journal of Tourism Research, 11(2), 185-199.

McGehee, N. G., Loker-Murphy, L., \& Uysal, M. (1996). The Australian international pleasure travel market: Motivations from a gendered perspective. The Journal of Tourism Studies, 7(1), 45-57.

Middleton, V. T. C., \& Clarke, J. (2001). Marketing in travel and tourism (3rd ed.). Butterworth-Heinemann.

Monteson, P. A., \& Singer, J. (2004). Marketing a resortbased spa. Journal of Vacation Marketing, 10(3), 282-287.

Mueller, H., \& Lanz Kaufmann, E. (2001). Wellness tourism: Market analysis of a special health tourism segment and implications for the hotel industry. Journal of Vacation Marketing, 7(1), 5-17.

Pesonen, J., Laukkanen, T., \& Komppula, R. (2011). Benefit segmentation of potential wellbeing tourists. Journal of Vacation Marketing, 17(4), 303-314.

Sangpikul, A. (2008). A factor-cluster analysis of tourist motivations: A case of U.S. senior travellers. Tourism, $56(1)$, 23-40.

Segal, M. N., \& Giacobbe, R. W. (1994). Marketing segmentation and competitive analysis for supermarket retailing. International Journal of Retail \& Distribution Management, 22(1), 959-552.

Sewall, M. A. (1978). Market segmentation based on consumer ratings o proposed product designs. Journal of Marketing Research, 15(4), 557-564.

Sharma, P., \& Nayak, J. K. (2019). An analysis on the emotional approach to segmentation: A study of yoga tourism. Journal of Convention \& Event Tourism, 2o(1), 1-23.

Sheldon, P. J., \& Park, S. Y. (2008) Sustainable wellness tourism: Governance and entrepreneurship issues. Acta Touristica, 20(2), 151-172.

Smith, M., \& Puczkó, L, (2009). Health and wellness tourism. Butterworth-Heinemann.

Smith, W. R. (1956). Product differentiation and market segmentation as alternative marketing strategies. The Journal of Marketing, 21(1), 3-8.

Su, D. N., Johnson, L. W., \& O’Mahony, B. (2020). Analysis of push and pull factors in food travel motivation. Current Issues in Tourism, 23(5), 572-586.

Suni, J., \& Pesonen, J. (2019). Hunters as tourists - An exploratory study of push-pull motivations. Scandinavian Journal of Hospitality and Tourism, 19(2), 175-191.

Swarbrooke, J., \& Horner, S. (2007). Consumer behaviour in tourism (2nd ed.). Butterworth-Heinemann.

Tkaczynski, A. (2009). Destination segmentation: A recom- 
mended two-step approach [Unpublished $\mathrm{PhD}$ dissertation]. https://eprints.usq.edu.au/6255/2/Tkaczynski _2009_whole.pdf

Tsai, C. Y, \& Chiu, C. C. (2004). A purchase based market segmentation methodology. Expert Systems with Applications, 27(2), 265-276.

Uysal, M., \& Jurowski, C. (1993). An empirical testing of the push and pull factors of tourist motivations. In Proceedings of 1993 CHRIE Conference (pp. 162-163). CHRIE.

Veal, A. J. (2006). Research methods for leisure and tourism: A practical guide. Pearson Education Limited.
Voigt, C., Brown, G., \& Howat, G. (2011). Wellness tourists: In search of transformation. Tourism Review, 66(1/2), 630.

Winter, F. W. (1979). A cost-benefit approach to market segmentation. Journal of Marketing, 43, 103-111.

Yankelovich, D. (1964). New criteria for market segmentation. Harvard Business Review, 42(2), 83-90.

Yoon, Y., \& Uysal, M. (2005). An examination of the effects of motivation and satisfaction on destination loyalty: A structural model. Tourism Management, 26(1), 45-56. 